\title{
3D Somatic Karyotype Analyses in Carthamus tinctorius
}

\author{
Anjali Malik ${ }^{1, *}$ and Anand Kumar Srivastava ${ }^{2}$ \\ ${ }^{1}$ Department of Microbiology, C.C.S. University, Meerut-250 004 \\ ${ }^{2}$ Department of Botany, C.C.S. University, Meerut-250 004
}

Received August 8, 2008; accepted November 8, 2008

\begin{abstract}
Summary Karyomorphological investigation have been carried out in ten different accessions of Carthamus tinctorius belonging to the tribe Cynareae (thistle), sub-family Tubifloreae of family Compositae. For concrete studies we explored the details of 3D karyotype using length and volume of the chromosomes and the chromosome complements, in addition to several other related parameters. The observations show variability pertaining to length and volume as well as morphology of chromosomes indicating the structural chromosome polymorphism. All the accessions possessed $2 n=24$ and symmetrical or slightly asymmetrical karyotype. The accessions belonging to the same species were showing intra-specific and inter-specific chromosome polymorphism.
\end{abstract}

Key words Carthamus, Karyotype, 3D analysis.

The genus Carthamus L. belonging to the tribe Cynareae (thistle), sub-family Tubifloreae of family Compositae has about 42 species with varying chromosome number of $2 n=20$ to $2 n=64$ and has a wide range of adaptation. C. tinctorius, commonly called safflower, is the only cultivated species of this genus. Commercially produced safflower seeds contain 32 to 52 percent oil. It is one of humanities oldest crop cultivated in India mainly for oil from the seeds and reddish and yellow dyes for clothing and food preparation from the flowers. The somatic chromosome analysis of the genus Carthamus is very difficult due to poor stainability, stickiness and tendency to overlap at metaphase and diffuse appearance of primary and secondary constrictions of the chromosomes. Three dimensional somatic karyotype were analyzed for establishing the chromosome and karyotype polymorphism.

\section{Materials and methods}

The present paper describes the three dimensional karyotypic analysis of different accessions of Carthamus tinctorius. The accessions that were used for somatic karyotype are listed in Table 1.

For investigating the somatic karyotype, roots were first pre-treated with $0.05 \%$ colchicine solution for about 3 to $4 \mathrm{~h}$ at $10^{\circ} \mathrm{C}$ in darkness. The roots were then washed thoroughly with water and fixed in 3:1 absolute ethanol and glacial acetic acid having a pinch of ferric chloride. The fixed root tip samples were stored in $70 \%$ ethanol in refrigerator. The root tips were smeared and squashed in $1 \%$ aceto orcein. Karyotypic analyses in cells exhibiting C-metaphase were performed in such temporary preparations. The somatic chromosomes were analysed from the photomicrographs using computerized Nikon Image Capturing system. The following parameters were used for the somatic karyotype analyses.

(a) Length of long arms, short arms and the whole chromosome, (b) arm's ratio, (c) total length of long arms (TLLA), all short arms (TLSA) and the whole chromosome (TLCC), (d) gradient index (GI), (e) symmetry index (SI), (f) radius of a chromatid of the chromosome of a complement and (g) total volume of long arms (TVLA), total volume of short arms (TVSA) and the whole

*Corresponding author, e-mail: anjali_malik7@hotmail.com 
chromosome of the complement (TVCC).

Arm's ratio, GI, and SI, were worked out using the below given formulae.

$$
\text { Arm's ratio }=\frac{\text { Length of long arm of a chromosome }}{\text { Length of short arm of a chromosome }}
$$

Table 1. List of accessions used for somatic karyotype analyses

\begin{tabular}{rrll}
\hline \hline S. No. & $\begin{array}{c}\text { Lab } \\
\text { Code }\end{array}$ & \multicolumn{1}{c}{ Species } & \multicolumn{1}{c}{ Source Country } \\
& & \\
\hline 1. & T-10 & Carthamus tinctorius & Afghanistan \\
2. & T-11 & Carthamus tinctorius & Afghanistan \\
3. & T-17 & Carthamus tinctorius & China \\
4. & T-24 & Carthamus tinctorius & China \\
5. & T-27 & Carthamus tinctorius & China \\
6. & T-28 & Carthamus tinctorius & China, Beijing \\
7. & T-30 & Carthamus tinctorius & China, Hunan \\
8. & T-32 & Carthamus tinctorius & Czechoslovakia \\
9. & T-33 & Carthamus tinctorius & Ethiopia \\
10. & T-34 & Carthamus tinctorius & Former Soviet Union \\
\hline
\end{tabular}

Table 2. Data related to karyotype of Carthamus accessions

\begin{tabular}{ccccccc}
\hline \hline $\begin{array}{c}\text { Lab } \\
\text { Code }\end{array}$ & Species & $2 n$ & $\begin{array}{c}\text { TLSA } \\
(\mu \mathrm{m})\end{array}$ & $\begin{array}{c}\text { TLLA } \\
(\mu \mathrm{m})\end{array}$ & $\begin{array}{c}\text { TLCC } \\
(\mu \mathrm{m})\end{array}$ & GI \\
\hline T-10 & Carthamus tinctorius & 24 & 21.93 & 25.03 & 46.96 & 50.00 \\
$\mathrm{~T}-11$ & Carthamus tinctorius & 24 & 24.17 & 25.20 & 49.36 & 59.68 \\
$\mathrm{~T}-17$ & Carthamus tinctorius & 24 & 27.26 & 30.87 & 58.14 & 69.70 \\
$\mathrm{~T}-24$ & Carthamus tinctorius & 24 & 24.51 & 24.94 & 49.45 & 71.19 \\
$\mathrm{~T}-27$ & Carthamus tinctorius & 24 & 21.24 & 23.74 & 44.98 & 60.00 \\
$\mathrm{~T}-28$ & Carthamus tinctorius & 24 & 26.14 & 33.33 & 59.48 & 57.18 \\
$\mathrm{~T}-30$ & Carthamus tinctorius & 24 & 26.32 & 27.35 & 53.66 & 57.58 \\
$\mathrm{~T}-32$ & Carthamus tinctorius & 24 & 24.60 & 27.26 & 51.86 & 59.70 \\
$\mathrm{~T}-33$ & Carthamus tinctorius & 24 & 23.39 & 25.11 & 48.50 & 62.71 \\
$\mathrm{~T}-34$ & Carthamus tinctorius & 24 & 24.25 & 27.45 & 51.70 & 62.31 \\
\hline
\end{tabular}

Table 2. Data related to karyotype of Carthamus accessions

\begin{tabular}{ccccl}
\hline \hline SI & $\begin{array}{c}\text { TVSA } \\
(\mu \mathrm{m})^{3}\end{array}$ & $\begin{array}{c}\text { TVLA } \\
(\mu \mathrm{m})^{3}\end{array}$ & $\begin{array}{l}\text { TVCC } \\
(\mu \mathrm{m})^{3}\end{array}$ & \multicolumn{1}{c}{ KF } \\
\hline 87.63 & 5.49 & 6.35 & 11.84 & $\mathrm{Y}[2 \mathrm{~B}(\mathrm{M})+20 \mathrm{C}(\mathrm{m})+2 \mathrm{D}(\mathrm{m})]$ \\
95.90 & 6.09 & 6.33 & 12.42 & $\mathrm{Y}[4 \mathrm{~B}(\mathrm{~m})+12 \mathrm{C}(\mathrm{M})+8 \mathrm{C}(\mathrm{m})]$ \\
88.30 & 6.95 & 7.79 & 14.74 & $\mathrm{Y}[8 \mathrm{~B}(\mathrm{~m})+10 \mathrm{C}(\mathrm{m})+6 \mathrm{C}(\mathrm{M})]$ \\
98.28 & 3.65 & 3.75 & 7.40 & $\mathrm{X}[2 \mathrm{~B}(\mathrm{M})+10 \mathrm{C}(\mathrm{M})+10 \mathrm{C}(\mathrm{m})+2 \mathrm{D}(\mathrm{M})$ \\
89.49 & 3.23 & 3.56 & 6.79 & $\mathrm{X}[20 \mathrm{C}(\mathrm{m})+2 \mathrm{C}(\mathrm{M})+2 \mathrm{D}(\mathrm{m})]$ \\
78.43 & 6.82 & 8.64 & 15.47 & $\mathrm{Y}[12 \mathrm{~B}(\mathrm{~m})+12 \mathrm{C}(\mathrm{m})]$ \\
96.23 & 3.96 & 4.15 & 8.12 & $\mathrm{X}[6 \mathrm{~B}(\mathrm{M})+12 \mathrm{C}(\mathrm{m})+6 \mathrm{C}(\mathrm{M})]$ \\
90.22 & 3.70 & 4.04 & 7.74 & $\mathrm{X}[4 \mathrm{~B}(\mathrm{~m})+16 \mathrm{C}(\mathrm{m})+4 \mathrm{C}(\mathrm{M})]$ \\
93.15 & 3.50 & 3.81 & 7.30 & $\mathrm{X}[2 \mathrm{~B}(\mathrm{~m})+20 \mathrm{C}(\mathrm{m})+2 \mathrm{C}(\mathrm{M})]$ \\
88.35 & 3.67 & 4.09 & 7.76 & $\mathrm{X}[4 \mathrm{~B}(\mathrm{~m})+20 \mathrm{C}(\mathrm{m})]$ \\
\hline
\end{tabular}



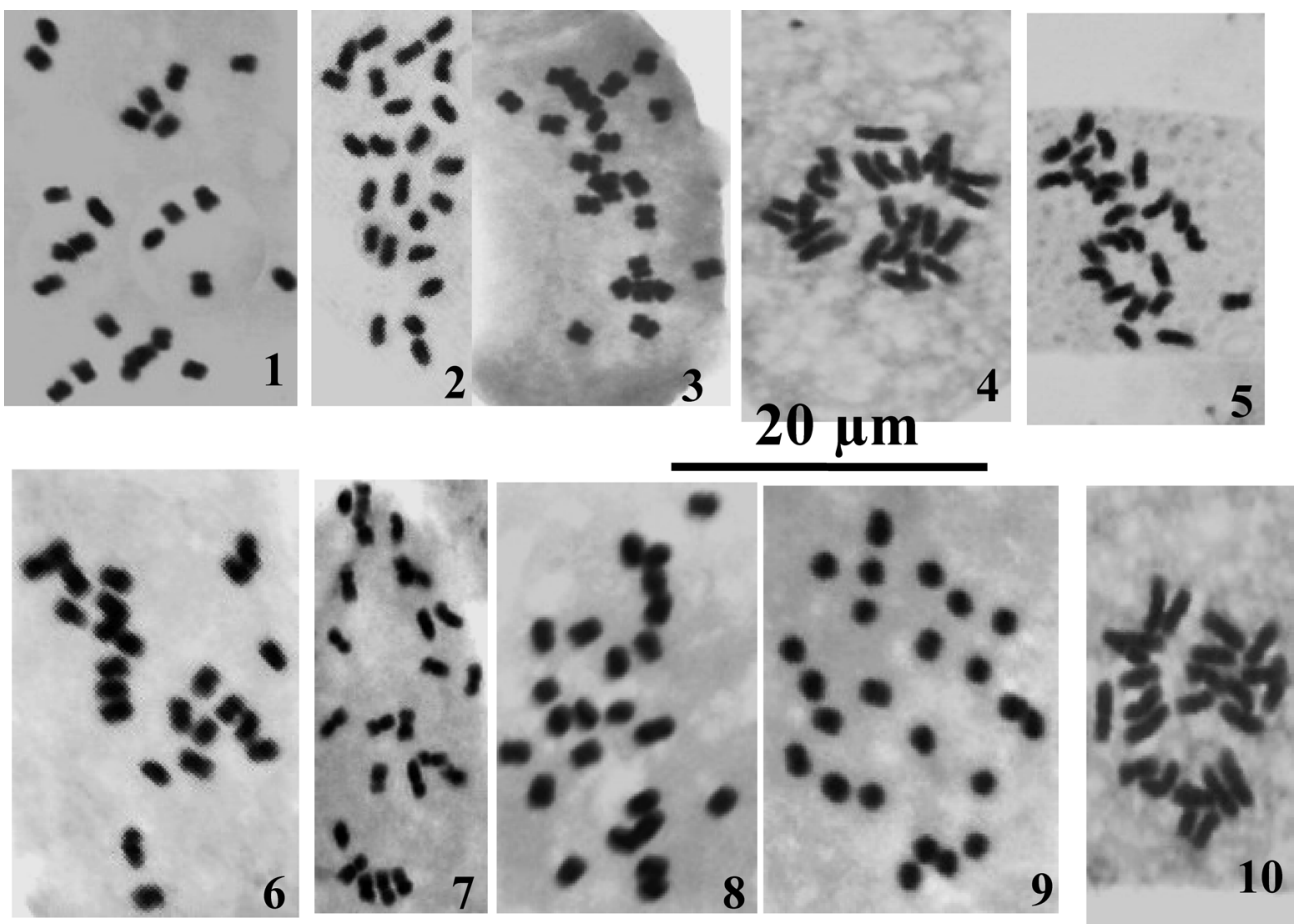

Figs. 1-10. Photomicrographs showing chromosomes in different Carthamus accessions (1) T-10 (2) T-11 (3) T-17 (4) T-24 (5) T-27 (6) T-28 (7) T-30 (8) T-32 (9) T-33 (10) T-34.

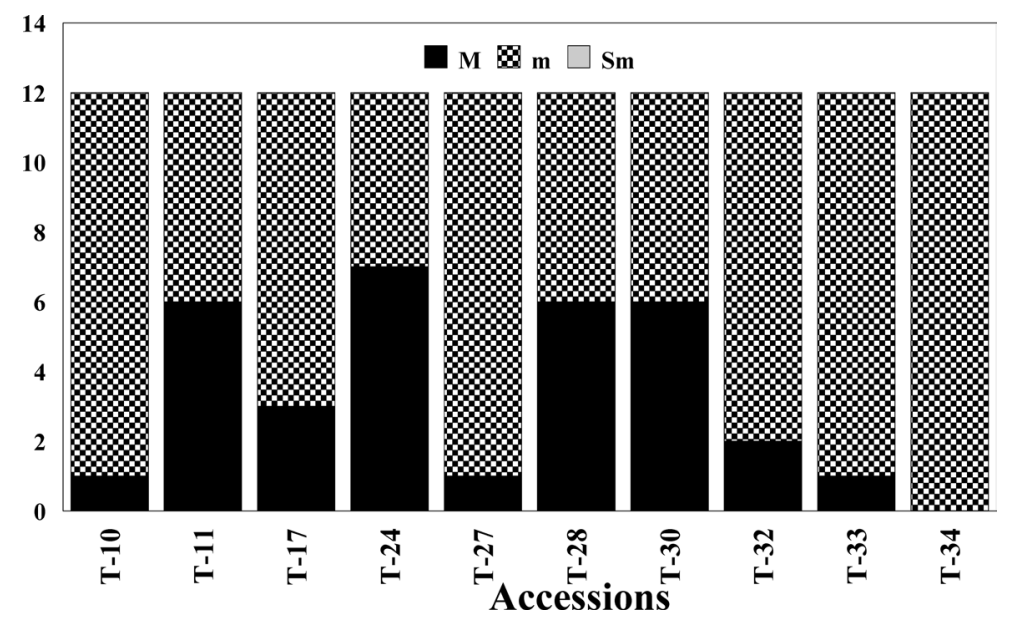

Fig. 11. Graphical representation of M, m and Sm types of chromosomes in different Carthamus accessions.

$$
\begin{aligned}
& \mathrm{GI}=\frac{\text { Length of shortest chromosome of the complement }}{\text { Length of longest chromosome of the complement }} \times 100 \\
& \mathrm{SI}=\frac{\text { Total Length of all short arms }}{\text { Total Length of all long arms }} \times 100
\end{aligned}
$$

The volume of each chromosome was measured assuming that it is made up of two cylinders corre- 

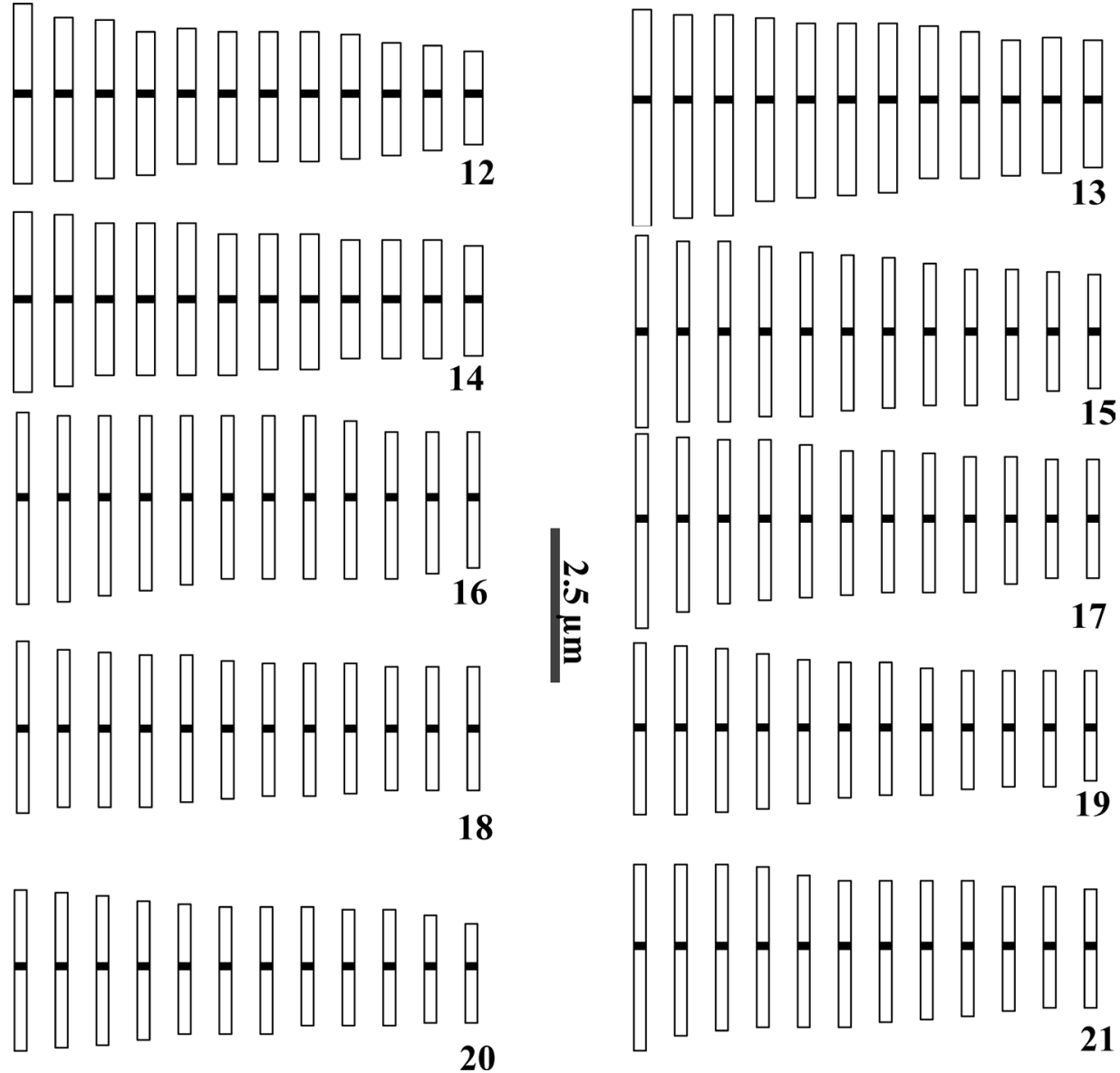

Figs. 12-21. Three dimensional ideograms of the gametophytic sets of somatic chromosomes in different Carthamus accessions (12) T-10 (13) T-11 (14) T-17 (15) T-24 (16) T-27 (17) T-28 (18) T-30 (19) T-32 (20) T-33 (21) T-34.

sponding to two sister chromatids. The chromosomes were assorted into different categories on the basis of arm's ratio following Levan et al. (1964) and were classified into four categories on the basis of total length, $\mathrm{A}-\mathrm{D}(\mathrm{A}=4.5-3.5 \mu \mathrm{m}, \mathrm{B}=3.5-2.5 \mu \mathrm{m}, \mathrm{C}=2.5-1.5 \mu \mathrm{m}$ and $\mathrm{D}=1.5-0.50 \mu \mathrm{m})$. The chromosome complements were also divided into four types, $\mathrm{W}-\mathrm{Z}$ using mean radius of the chromatids of the complement $(\mathrm{W}=0.10-0.15 \mu \mathrm{m}, \quad X=0.15-0.20 \mu \mathrm{m}, \quad Y=0.20-0.25 \mu \mathrm{m}$, $\mathrm{Z}=0.25-0.35 \mu \mathrm{m})$. Further, the chromosome complements were divided, as per Stebbins (1958) into different categories on the basis of arm ratio.

\section{Results and discussion}

All the accessions possessed a chromosome number of $2 \mathrm{X}=2 n=24$. For 3 -D analysis of the somatic karyotype, the parameters listed with materials and methods were analyzed.

Data pertaining to somatic karyotype analyses, based on the length and volume parameters of the chromosomes and chromosome complements, are listed in Table 2.

Table 2 also contains karyotypic formulae for somatic karyotypes of all the accessions analyzed. Photomicrographs of the typical somatic cells showing C-metaphase chromosomes are de- 
picted in Figs. 1-10. Graphical representation of M, m and sm types of chromosomes are presented in Fig. 11. 3-D ideograms of the gametophytic set of somatic chromosomes are depicted in Figs. 12-21.

A perusal of the data pertaining to somatic karyotype clearly indicated the presence of interspecific and intraspecific polymorphism. The minimum total length of the chromosome complement was observed for T-27 while the maximum total length of the chromosome complement was observed for T-28. The maximum volume of the chromosome complement was observed for T-28 while the minimum volume of the chromosome complement was observed for T-27.

Most of the chromosomes of Carthamus accessions were of ' $\mathrm{m}$ ' and ' $\mathrm{M}$ ' type. The type of karyotype present in different accessions as per Stebbins (1958) belonged to either 1A or 1B type.

The details of somatic karyotype were analyzed using the parameters as per Srivastava and Purnima (1990) and Srivastava and Kalra (1996). Comparison of the data related to length and volume of the gametophytic sets of the somatic chromosomes of different accessions revealed very clearly that a direct correlation between length and volume of the chromosome complement did not exist. The volume of a chromosome depends upon the length as well as thickness. Therefore, this set of observations indicated that the length of the chromosome complement should not be taken as the only parameter for deciding the variability in the amount of genetic material. However, the thickness of the chromosome is also dependent on the density of the chromatin within the chromosome. The somatic karyotype of the accessions belonging to the same species differs from each other in addition to the length and volume of the chromosomes, in other features like the frequency of ' $\mathrm{M}$ ' and ' $\mathrm{m}$ ' chromosomes. Further the chromosomes of somatic karyotypes were classified into different categories using arm's ratio as per Levan et al. (1964). In general, chromosomes of 'M' and ' $\mathrm{m}$ ' were present in high frequency in somatic chromosome complements. Stebbins (1958) classification for the types of the karyotype was used for differentiating the somatic karyotypes of various accessions into different categories. The chromosomes were belonging to $1 \mathrm{~A}$ and $1 \mathrm{~B}$ types only and therefore, could be considered symmetrical or slightly asymmetrical. The accessions belonging to the same species were showing intra-specific chromosome polymorphism. Three-dimensional analyses of somatic karyotype in some accessions of C. glaucus, C. oxycantha, C. palaestinus, C. tinctorius, and C. tinctorius subsp. turkestanicus have been conducted by Srivastava and Kalra (1996). Some of the accessions of this species presently analyzed were agreeing for their karyotypes with their observations. Somatic karyotype analyses have also been conducted earlier by a number of workers like Knowles and Schank (1964), Estilai and Knowles (1976, 1978, 1980), Chatterji and Rathore (1972-73), Pillai et al. (1981a) and Jayaramu and Chatterji (1986). However, these workers did not carry three dimensional analyses of the somatic karyotype.

\section{Acknowledgements}

The senior author is grateful to Prof. (Dr.) A. K. Srivastava, Head Department of Botany C. C. S. University Meerut for providing necessary facilities to carry out the work.

\section{References}

Chatterji, A. K. and Rathore, O. S. 1972-73. Cytological studies in different cultivated varieties of safflower Carthamus tinctorius L. J. Cytol. Genet. 7/8: 17-23.

Estilai, A. and Knowles, P. F. 1976. Cytogenetic studies in Carthamus divaricatus with eleven pairs of chromosomes and its relationship to other Carthamus species (Compositae). Am. J. Bot. 63: 771-782.

- and - 1978. Relationship of Carthamus leucocaulos to other Carthamus species (Compositae). Can. J. Genet. Cytol. 20: $221-223$.

— and - 1980. Aneuploids in safflower. Crop Sci 20: 516-518.

Jayaramu, M. and Chatterji, A. K. 1986. Karyological studies on Indian wild safflower Carthamus oxycantha M B. Cary- 
ologia 39: 179-184.

Knowles, P. F. and Schank, S. C. 1964. Artificial hybrids of Carthamus nitidis Boiss. and C. tinctorius L (Compositae). Crop. Sci. 4: 596-599.

Levan, A., Fredgra, K. and Samber, A. A. 1964. Nomenclature for centromeric position on chromosomes. Hereditas. 52: 201-220.

Pillai, R. S. N., Kumar, H. and Singh, R. B. 1981a. Karyotype analysis of safflower. Crop. Sci. 27: 809-811.

Srivastava, A. K. and Purnima. 1990. Numerical and structural inconstancy in Belamchanda chinensis DC (Iridaceae). Proc. Indian. Acad. Sci. 100: 205-210.

— and Kalra, R. 1996. Three dimensional analysis of karyotype in Carthamus. J. Cytol. Genet. 31: 139-144.

Stebbins, G. L. 1958. Longivity habitat and release of genetic variabiality in the higher plants Cold Spring Harb. Sym. quant. Biol. 23: 365-378. 